\title{
Impact of Technology Advancement on the Malaysian Ethnics Festival Foods and its Foodways
}

\author{
Rosmaliza Muhammad, Mohd Salehuddin Mohd Zahari, Mohd Shazali Md. \\ Sharif \\ Faculty of Hotel \& Tourism Management, \\ Universiti Teknologi MARA (UiTM), Shah Alam, Selangor, 40450 Malaysia \\ ieza_zm@yahoo.com
}

\begin{abstract}
This study explores the impact of technology advancement in Malaysian ethnic festival foodways and how it affects the practices of young generations. The informers involved three major ethnics groups (Malays, Chinese and Indian) in Klang Valley, Malaysia. The alteration eases the heavy burden or workload in preparation and consumption of festival food. It introduced the emergence of cooking equipments and new utensils. The traditional equipment used has gradually been overtaken by modern equipment. The preparation festival foods are becoming much faster, effective and efficient. Nevertheless, the alterations explicitly lessen the practices of foodways among the community members particularly the young generations.
\end{abstract}

Keywords: Ethnic Festival foods; Foodways; Malaysia; Practices

eISSN 2398-4295 @ 2018. The Authors. Published for AMER ABRA cE-Bs by e-International Publishing House, Ltd., UK. This is an open-access article under the CC BY-NC-ND license (http://creativecommons.org/licenses/bync-nd/4.0/). Peer-review under responsibility of AMER (Association of Malaysian Environment-Behaviour Researchers), ABRA (Association of Behavioural Researchers on Asians) and cE-Bs (Centre for EnvironmentBehaviour Studies), Faculty of Architecture, Planning \& Surveying, Universiti Teknologi MARA, Malaysia.

DOI: http://dx.doi.org/10.21834/ajbes.v3i10.80 


\subsection{Introduction}

Festivals are one of the most important cultural practices for almost all nations in the world. According to Getz (1991) a festival is a way of celebrating a specific theme, a season, a culture, the time of the year and to highlight a cultural asset. It encompasses elaborate customs and traditions in every step of the process from the planning stage to the actual day. Guldan (2000) argued that festivals are influenced either by religion, culture and customary practices. Aidil Fitri and Aidil Adha for Muslims, Christmas for Christians and Deepavali for Hindus are a few of the religious festivals or celebrations while Lantern Festivals for the Chinese, Light Festivals for the Jewish and Chu Sok for the Koreans are examples of cultural and customary practices. There are many other cultural and customary festivals celebrated, with either ritual or music, performing an essential role during the celebrations, and these practices vary among countries, social classes and ethnic groups.

Yassin (1999) however posits that, for whatever reasons, festivals are less successfully organized without the presence of food. Food through its preparation and consumption, popularly known as foodways, has in fact long held a central position in any festival. These foodway practices not only act as a social event but as a catalyst for the interrelationships, interactions and social bonding among the individuals in the family and community (Gutierrez, 1999; Freeman, 2002; Cusak, 2003; Vu, 2009). Many people contend that food and festivals are strongly associated with all ethnic groups (Sani 1999; Fukutomi, 2002; Bayan, 2007) and ethnic festival foods are the kind of food that is often prepared by ethnic groups for their festival celebrations (Kroll, 1994).

In Malaysia, lemang, rendang, ketupat and a few others, for instance, are synonymous with Malay religious festivals such as Hari Raya (Hari Raya Aidilfitri and Hari Raya Aidiladha). During these festivals, lemang is prepared using glutinous rice and cooked in bamboo tubes while ketupat is made from rice or glutinous rice and wrapped in leaves. These foods are accompanied by rendang which is cooked using meat or chicken with chili and herbs. It is no exaggeration that the Hari Raya celebration is dull without the presence of these foods (Muhammad et al., 2009). There are also many other types of foods prepared for these religious and cultural festivals.

Nian gao along with vegetables, oysters, abalone, carp, duck or chicken is one of the special and most important dishes for the Chinese New Year festival and other celebrations (Lee, 1986). This traditional cake is made from glutinous rice, flour, water and sugar, and wrapped in leaves and served not only to family members and relatives but also to the guests during the festival. The Chinese believe that this cake symbolizes unity and togetherness among family members and friends. Deepavali, the Hindu religious festival, is considered meaningless without the presence of lamb massala, gobi pakoras, aloo gobi, idlis, puri, vadai, ommapadi, especially appom, ponggal and aatherasam. The traditional sweets and desserts such as jelebi, murukku, gulab jamun, ladu, palkova and kesari are also present in this festival. These foods are important in the Indian festival and without them the prosperity and happiness of the Indian family are believed to be lessened until the next Deepavali (Leong, 1992). It is the same with other ethnic festivals such as Pesta Kaamatan, Pesta Gawai, Pesta Menuai and many more. During Pesta Kaamatan for instance, pansuh and tubu are 
special foods for the Kadazan-dusun ethnic group. Again, this festival is considered incomplete without the presence of those inherited foods.

The vast ethnic festival food treasures however are believed to have been permanently altered by the technology advancement. It is therefore believed that technology has somewhat influenced the alteration of Malay, Chinese and Indian ethnic festival food and its foodways. In addition, the alteration in preparation may involve ingredients, equipment and cooking methods. Similarly to consumption, it is assumed that eating utensils and styles of serving of the festival foods are also changed. The young generations of each ethnic group in this study are assumed to less able to prepare their traditional festival foods. Therefore, this study explores the impact of technology advancement in Malaysian ethnic festival foods and its foodways and how it affects the practices of young generations.

\subsection{Literature Review}

Food is accepted as one of the most basic requirements for human existence, it is no surprise that it also forms a basic cultural component and it is contended that human interaction with food is the determinant of what can be considered as culture. Food and its consumption relate to the formation of nationhood which is the making of a sense of identity for the society and the thread that binds people together (Powell, 2007). Guldan (2000) described the role food and cuisine played in the development of the national identity, as it is in the preparation and consumption of food or foodways that the society expresses its customs, traditions and culture.

Nevertheless, Martinez (1987) argued that foods like living things are sensitive or involve changes. This process not only relates to food itself but it also the culture of it. For instance 'creolization' which started from one food culture changed into two or more food cultures and they produced a new culture when they reached America (James, 1997). Micheal (2000) noted that societies are continually changing and social changes are reflected in food and eating practices. Cwiertka (2000) found that industrialization, urbanization and modernization have a major impact on the production and consumption of traditional food in Japan which is strongly linked to social change. Sobal (2000) used the term social dynamics to refer to large scale social changes. He asserted that food and eating practices as well as the patterns of a society have been referred to in many ways, each of which offers different perspectives for the analysis of social dynamics.

Gillette (2005) noted that some behavioural shifts are occurring in the preparation and consumption of food, and the local food consumption practices, particularly of the traditional food have been reduced and this is largely associated with modernization. Food modifications or changes are also influenced by the new trends in consumption which Miele (1999) described as the emergence of a post-modern circuit of food and the rise of a new culture of consumption among consumers which slightly contributes to the changes. Within the context of her study, two bodies of work were formed. One relates to the issue of the globalization of the agri-food system and the other to the social relations and cultural forms of the food changes produced. 
Modernization is also a structural change that involves technological development and adoption of materials (Inkeles \& Smith, 1974). Sobal et al., (1998) and Sobal (1999) identified that the production, processing and distribution of food were extensively shaped by modernization. Rogers (2005) investigated the matter within the topic of equipment replacement under continuous technological change. She identified two types of technological advancement which are discontinuous and continuous technological change. The discontinuous technological change represented by jumps in improvement with each new vintage arrival and the continuous technological change are represented by incremental improvement with each release of the same vintage. Sobal (1999) reflected on the changes that have taken place in the area of food and beverages which he claimed to be one of the most complex activities within the area of hospitality. Although, technological advances, particularly in the kitchen, and the invasion of modern business techniques, such as branding and business process engineering, have brought new activities, the need for the traditional knowledge and skills remains. Modernization also contribute to the changes of people lifestyle (Othman et al., 2012)

According to Li, Yin \& Saito (2004), a few traditional food practices are on the verge of being lost, but improvements through modernization benefit food industries, especially in the poorer regions and suggested more of them need some improvements with the existence of the modern world. However, they were looking at it from the perspectives of healthy eating habits. Bermudez \& Tucker (2004) mentioned that the food-related practices of older people of any ethnic group provide challenges including the increase in requirements for important nutrients. This is because of the physiological changes associated with aging and the pathological effects of some chronic conditions. They pointed out that eating practices are ruled not only by physiological demands, food availability and choices, but also by cultural norms, knowledge and information, and access to food, which is often determined by economic conditions. Overall, the foodways that relate to the preparation and consumption as well as the appearance and acceptance of the food are slightly changing due to modernization.

\subsection{Methodology}

Face to face interviews as part of qualitative techniques were used in obtaining the required information from the ethnic informers. Fifteen influential individuals who are involved in festival events ( 5 Malays, 5 Chinese and 5 Indians) were chosen as the sample as they are believed to have vast experience in providing relevant information on the subject matter. As this study will probably provide a fundamental basis for other potential studies in the future, owing to the rarity of such studies undertaken in Malaysia, using one or two contextual settings for data collection is considered sufficient and acceptable (Berg, 2004). Therefore, Shah Alam and Klang districts were chosen as contextual settings for data collection.

The respective informers were identified through screening questions beforehand, as a way to verify whether the sample was appropriate for the interview (Morse et al., 2002), which incrementally contributed to ensuring the reliability and validity of the research data. The 
interviews were tape-recorded and transcribed in the original language (Hussey \& Hussey, 1997).

\subsection{Results and Discussion}

\subsection{Characteristics of the informers}

The ethnic informers consist of Malays $(n=5)$, Chinese $(n=5)$ and Indians $(n=5)$ which females $(60 \%, n=9)$ are greater than males $(40 \%, n=6)$. Majority of the informers $(53 \%, n=8)$ were aged 61 to 65 years old, 40 percent $(n=6)$ of them were 50 to 60 years old and one of the informer $(n=7)$ aged 68 years old. The experience in festival food preparation particularly act as a food leader is important as the study purpose to gather the opinion from the experts in food preparation which in turn, majority of the ethnic informers $(67 \%, n=10)$ have 10 years experiences in food preparation in their residential areas. In addition, three of the informers $(20 \%)$ having 16 to 20 years of experience and 2 of the other informers (13\%) have more than 21 years experiences in food preparations.

\subsection{Informers View on the Impact of Technology Advancement on Ethnics Festival Foods and Its Foodways}

The question asked the ethnic informers of do you believe that modern technologies influence the alterations in preparation and consumption of your ethnic festival foods and how far it altered the preparation and consumption of the foods? In respond to the question, majority of them agreed that technology directly influenced and thus altered the preparation and consumption of festival foods. Some of the responses are as follows.

\section{Eases the preparation}

Alteration according to the informers involved the ingredients, cooking equipments and the eating utensils. The advancement of technology in those particular aspects assists and eases the preparation not only daily but also to the festival foods. Quoted directly from one of the informer;

"I believed technologies influence the festival foods preparation. Well, it is a big different between my teenager's time and now! New technology altered the preparation not only our daily foods but also festival foods. For instance, in the olden days, before Hari Raya... we need to prepare foods like baulu, semperit, putu kacang and rempeyek... one or two weeks earlier. In the preparation of baulu, you know...we do not have mixer........ we use wood type of spoon and coconut sticks or lidi which were formed like a whisk. You know... it is very tiring...beating the eggs to get it foam. I still remember...we used coconut husk fibre for the baking purposes. Similar to semperit, the square aluminum tin ovens were used for baking which was put on the stove. But now.... with the modern technology, you can use electrical mixer and oven or you name it. Even we have varieties of baulu size and shapes. It is easier".

(Malay informer 3) 


\title{
The apparent of convenience ingredients
}

Some of the informers on the other hand answered the question by looking at technology through the apparent of convenience food ingredients or products. The following informers stressed that;

\begin{abstract}
"Technology.... of course moderately altered our festival foods. In the olden days, during Hari Raya or wedding ceremony we used pestles to get the green color of pine screw leaves for our traditional kuih. But now....it is in substitute form and you can get it from any shops not only for green color, but also others like red, purple and many more! You see...we have so many sophisticated technologies. Similar goes to our food flavor. We have varieties of new flavors. You just picked which one that you prefer....vanilla, cappuccino, chocolate...hmmm ...everything is ready for you."
\end{abstract}

(Malay informer 1)

"I do believe technologies influence our festival foods. You also can see it. We now have convenience ingredients in powder forms, dried, frozen, sachets or pastes. All these modified the preparation of our festival foods you know!.... Look at lemang ...we traditionally use bamboo, glutinous rice, coconut milk and banana leaves. It is very hot when you have to take care of it and it takes much time to cook them. But...it is fun you know. I wonder how the convenience lemang in packet forms apparent. No joke you can find them in the market now. Similar to nasi impit, $t$ it comes in a various packet forms and you just need boiled it. I hardly see people cooked nasi impit in typical traditional way. Probably some still practice. You see... technology slightly altered our festival foods ingredients."

(Malay informer 5)

\section{Modern eating utensils}

Modern eating utensils are also claimed have modifying the consumption of festival foods. Paper, plastic and Styrofoam types of plates, bowls, cups, spoons, forks, tissue paper and chafing dishes are some of the examples. These utensils ease and decreased the usage of manpower in festival celebrations. The same notion was given by two informers. As noted by them;

"Technologies!! pretty much alter our traditional consumption of foods during festival celebrations. We now have various types of plastic food container and Styrofoam like plates, cups, bowls, spoons and forks. These modern utensils are apparent among us particularly for Hari Raya, majlis tahlil, kenduri kesyukuran and majlis cukur jambul. Instead of traditional pots, saprah and finger bowls, we are now using chafing dishes, tables and tissue papers. These tools ease our jobs in food preparation and reduce manpower. Hmm...now...everything is quite different."

(Malay informer 5)

"..food containers are also used for the packaging purposes like tapai, our popular fermented dessert. We traditionally wrapped tapai in banana or rubber leaves. But owing to the convenience, people now tend to use plastic containers as well. Another example is ketupat. It has been so long people used daun palas in making the traditional ketupat. Now, the convenience ones can easily be found in the market. Don't question me about the taste.... Similar to rendang. 
$\mathrm{Hmm}$.....instead of tamarind juice, we now used tamarind paste and some of us add mint leaves. The original or traditional taste of rendang is now different if we add with other ingredients."

(Malay informer 2)

\section{Modern equipments}

Owing to the difficulties in food storage in the olden days, one of the informer through her experienced claimed that some of raw materials for festival foods hastily deteriorated or become easily rotten. With a few examples, she uttered that;

"To me...technologies do influence our storing of food. In the olden days, it is hard to keep raw materials because we don't have refrigerator or freezer like what we have now! We always prepared the raw materials just before the festival celebrations. You know, for wedding ceremony or kenduri berkhatan, we normally prepared the raw materials in the morning of the kenduri itself due to the storage problem. Villagers who involved with the food preparation were also busy with their tasks and the head of food preparation need to ensure that the foods were ready to be served on time! Sometimes we were not sleeping.just preparing the raw materials and foods. But now...it's different. You see.... with the technologies, we are able to prepare our raw materials earlier and stored it in the refrigerator. It is easy and saves a lot of our time."

(Malay informer 4)

Besides those notions, this 61 old lady further asserted;

"we also have various types of equipments like stoves, oven, mixer, chopper, heat ventilator, stainless steel pots and others."

Another informer shared her feeling and responded that;

"the modern technologies... of course it altered our festival foods as it save time for preparation. You don't have to wait long in preparing dim sum, nian gao and shark fin soup. Various modern cooking equipments such as steamers, oven, stoves, mixer and others save your time. We can easily prepare the festival foods. However, some of the Chinese do not prefer to cook and they much prefer to eat at restaurants. They want to save their time in food preparation because they have a good financial condition."

(Chinese informer 2)

The improvisation of the traditional equipments made from woods, bamboo and clays such as basket steamers, chopsticks, bowls, cups, clay pots and wok were also stressed. These equipments despite preserving their uniqueness, the materials used are much advanced, handy and resistance. This was reported by some of the informer. As quoted from them;

"...the technology somehow modified and improvised our traditional equipments. Well...in the past, woods, bamboos and clay types of equipments were commonly used. Clay pots, wok, chopsticks, cups, bowls and basket steamers are the examples. The preparation of our festival foods normally took a longer time using those traditional equipments. Our moon cake and nian gao for instance, we use traditional bamboo steamer to bake them. We now 
have a lot of modern cooking equipments from steels... I noted that. There are much advanced, handy and resistance.... which is good for us. "

(Chinese informer 5)

The varieties of modern cooking equipments are also apparent due to the advancement of technology as stressed by one of the informer. She explained;

"With technologies...we have more roasting and baking ovens, rice cooker, skillet, steamer, freezer, refrigerators, heat ventilation, chopper, food processers, toasters, varieties of chopsticks, bowls, pots and others. The preparations of our festival foods become easier."

(Chinese informer 3)

\section{Availability of convenience food}

Availability of convenience food through the food processing technology which directly influence mood of cooking among the Chinese during the festival celebrations also raised out during the interview by some of the informer. They noted;

"Technology somewhat changed our foods including the festival foods. It influences the preparation and consumption of these foods. I'm not saying technology is not good to us, but it sometimes may change our tradition or old styles of life. Convenience foods and canned foods in the market for instance, are highly bought by the Chinese during the festival celebrations. Some of them are not preparing the festival foods themselves! It is become worst when everybody started to serve the canned or bottles beverages to their guests. You see...how easy to prepare the drinks, but everybody still prefer to buy the convenience one!"

(Chinese informer 1)

"Of course the modern technologies moderately influence and altered our festival foods. Some of our traditional festival foods are no longer prepared manually or homemade...we have modern appliances...even we can get the convenience ones from the market. It eases the people in preparing the foods. Before this, if you're busy or do not have much time in preparing the festival foods, you still need to spend your time to cooked the foods for the celebration, but now....you don't have to worry! With the modern technology....everything is ready and available for you."

(Chinese informer 4)

As of Malays and Chinese, similar kind of answers was gathered from the Indian informers. Therefore, this analysis only revealed the remarkable findings or something different from the preceding ethnics' responses. In relation to that, besides others, the advancement of modern equipments not only eases the burden of preparation but also given significant impact on the togetherness among the young generation. For instance, the informers expressed that;

"... technology slightly changed the preparation of our festival foods and ease the burden. 
We cook our daily and festival foods using charcoal stoves and sharashi (tongs) to hold hot cooking pots during 60's. Now, everything has changed. No more sharashi! We have a lot of modern cooking equipments like aluminum pots, spoons, forks, ladders, mixer, blenders, stove, oven and others. Most importantly is that, our young people are lucky... as they do not feel the burden like what we have experienced in preparing the festival foods. Despite that, our skills are much better than them. Would you agree with me?"

(Indian informer 3)

\section{Lack of the uniqueness of food}

The alteration of uniqueness of festival foods in terms of serving styles and eating decorum were part of the discussion. Instead of thalis, modern eating utensils are popularly used during the Indian festival celebrations. The informers for instance stressed out;

"The technologies.... well....for sure....it moderately altered our festival foods. You know, Hindus are strong believers in traditions. Almost all the traditions that have influenced the daily life of Hindu in Malaysia have been carried over from their country of origins. Similar goes to our tradition in the festival foods consumption. Our thalis (silver tray) and banana leaves are popularly used when we eat together during the festival of Deepavali, Pongal, Vasakhi and also wedding ceremony. We will seat together and somebody will come to serve the foods. It is very unique and enjoyed, you know! Now...you see what happened. We use paper plates, cups, spoons and forks when we eat the idli, curry, aatheresam and many more. No need to wash thalis. It is easy, right!"

(Indian informer 4)

"It is hard to find our traditional shil noda (grindstones) in most of the Indian houses. Well....everybody uses blender and food processer in preparing their curry and other foods for Pongal and other celebrations. In the olden days, we normally used charcoal stove for jelebi and laddu preparation....but now...no more! Electrical and gasses stoves are now used to cook those festival foods including aatteheresem. l've actually doubt with the taste... of course....it is different with the original taste."

(Indian informer 1)

\section{Lack of togetherness among the community}

Technology reduced the aspects of togetherness among the Indian community particularly in their families during the preparation of the festival foods as reported by some of the informers. One of the responses was quoted from them;

"Well....technology directly influences our festival foods particularly in the preparation aspects. In the past, all the family members work together in the food preparations. All of us were given a few tasks and sometimes.....we do it by a group. Now...in the festival food preparation, we have modern equipments. of course it ease our job during the festivals because it reduce the manpower and the involvement of family members. However, sometimes....the togetherness among us is lessening because the children and teenagers do not involve in the preparations."

(Indian informer 2) 


\subsection{Conclusion}

The technologies are slightly altered their festival foods not only in the preparations but also the consumptions. The elements of traditional aspects particularly from the aspects of ingredients, cooking equipment and eating utensils are found have slightly modified with the apparent of convenience ingredients and modern equipments. The adoption the modern aspects in the festival food ways contributes a lot of advantages, Nevertheless, the modernization through the technologies has given significant impact on the togetherness particularly among the young generations as well as reduced cohesiveness, social bonding and interaction among the ethnics society. The limitation of this study is based on sampling whereby only two areas were chosen (Klang and Shah Alam), thus the findings could not be generalized to all Malays, Chinese and Indian populations in the whole nation. Replication using broader sampling size is recommended. The findings therefore may assist stakeholders to better understand how modernization significantly shifts the Malaysian ethnic festival food ways and plan ahead for any campaign and cultural activities to preserve the uniqueness of Malaysian ethnic foods treasures.

\section{References}

Bayan. (2007). Nilai Sebuah Majlis Perkahwinan. Retrieved July 10, 2009 from http://psittacula.wordpress.com/2007/

Berg, L.B. (2004). Qualitative Research methods for the Social Sciences. California: Pearson Education Inc.

Bermudez, O. I., \& Tucker, K. L. (2004). Cultural aspects of food choices in various communities of elders. Food and Nutrition for Healthier Aging, 22-27.

Cusak, I. (2003). Pots, pans and eating out the body: Cuisine and the Gendering of African nations. Nations and Nationalism Journal, 9, 277-296.

Cwiertka, K.J. (2000). Encounters and Transitions in Foodways: Japan and the West. Food Culture, 8-11.

Getz, D. (1991). Festivals, Special Events and Tourism, New York: Van Nostrand Reinhold

Gillette, M. (2005). Factory Food, Modernization and Race. Beyond Islam: Understanding the Muslim World Curriculum. World Affair Council. Retrieved August 2, 2009 from http://www.world-affair.org

Guldan, G. (2000). Infant and Feeding Transition in China and Hong Kong: Is it a Healthy Development? In Jing, J. (Ed) Feeding China's Little Emperors: Food, Children and Social Change. Stanford: Stanford University Press.

Gutierrez, P. (1999). Cajun Foodways. Missisippi: University Press.

Freeman, E. (2002). The Wedding Complex: Forms of Belonging in Modern American Culture. Durham: Duke University Press.

Fukutomi, S. (2002). Pot Au Feu Japan: Foods and Weddings. Unpublished master dissertation, Lousiana State University. Retrieved on Mei 17, 2009 from website http://www.proquest.com.

Hussey, J. And Hussey, R. (1997). Business research: a practical guide for undergraduate and postgraduate 
students, Great Britain: Palgrave.

Inkeles, A., \& Smith, D. (1974). Becoming modern: Individual Change in Six Developing Countries. Havard: Harvard University Press.

James, D. (1997). Courtesans and Fishcakes: The consuming passions of classical Athen. London: Harpe Collins Publishers.

Kroll, D. Prepared ethnic foods: trends and developments, Business Communications, July 15, 1994, pp. 9-14

Lee, S.M. (1986). Spectrum of Chinese Culture. Kuala Lumpur: Pelanduk Publication.

Leong, G. (1992). Festivals of Malaysia. Kuala Lumpur: Pelanduk Publication.

Li, L. T., Yin, L. J., \& Saito, M. (2004). Function of traditional foods and food culture in China. Journal of Agriculture, 38(4), $213-220$.

Martinez, R. O. (1998). Globalization and the social sciences. The Social Science Journal, 35, 601-613.

Micheal, L. E. (2000). Modernization as Ideology: American Social Science and 'Nation Building' in Kennedy era. New York: University of North Carolina Press.

Mieli, M. (1999). Short circuits: new trends in the consumption of food and the changing status of meat. International Planning Studies, 4(3), 373-387.

Morse, J.M., Barret, M., Mayan, M., Olson, K. And Spiers, J. (2002). Verification strategies for establishing reliability and valisity in qualitative research. International Journal of Qualitative Methods, 1(2).

Powell, J. (2007). Immigration. New York: Thomas Woll.

Rogers, L. J. (2005). Equipment replacement under continuous and discontinuous technological change. A Doctoral dissertation, University of Lehigh, United State of America.

Riley, M. (2005). Food and beverage management: a review of change. International Journal of Contemporary Hospitality Management, 17(1), 88-93.

Muhammad, R., Zahari, M. S. M., Othman, Z., Jamaluddin, M. R., \& Rashdi, M. O. (2009). Modernization and Ethnic Festival Food. Paper presented at the International Conference of Business and Economic, Kuching, Sarawak.

Sani, F. M. (1996, Jun). Pengantin dan Belanja Besar. Al Islam.

Sobal, J., Khan, L.K., \& Bisogni, C.A. (1998). A conceptual model of the food and nutrition system. Journal of Social Science and Medicine, 47, 853-63.

Sobal, J. (1999). Food System Globalization, Eating Transformations, and Nutrition Transitions. In R. Grew (ed.) Food in Global History. Boulder: Westview Press.

Sobal, J. (2000). Social Change and Foodways. Food Resource Nutrition and Food Management, Oregon State University, Corvallis retrieved July 10, 2009 from: http://food.oregonstates.edu

Vu, V. (2009). The Changing Foodways of Vietnamese Americans in Orange County, California. Unpublished master Dissertation, California State University. Retrieved on April 25, 2009 from website http://www.proquest.com 
Muhammad, R., et.al. / Asian Journal of Behavioural Studies (AjBeS), 3(10) Mar / Apr 2018 (p.53-64)

Yassin, S. M. (1999, July). Rewang: Perpaduan Tulen Jiran Sekampung. Dewan Budaya, 28-29.

64 